\title{
Türkiye'de Uygulamalı Sosyal Bilim Sorunsalı: Uygulamalı Psikoloji Ekseninde Bir Değerlendirme
}

\author{
Zehra Erşahin \\ Ankara Sosyal Bilimler Üniversitesi, Uygulamalı Psikoloji Anabilim Dalı / Ankara \\ ORCID: Z.Erşahin (0000-0002-9349-8586)
}

\begin{abstract}
Özet
Bu çalıșma, sosyal bilimlerin ülkemiz coğrafyasında Psikoloji bilimi bașta olmak üzere üniversitelerin eğitim ve politikalar bağlamında yaşadığı uygulama sorunlarını, uygulama temelli bir bilim anlayışının oluşturulmasına engel teșkil eden süreç ve dinamikleri ve buna karşı üniversitelerin bir sorumluluk hassasiyetiyle üstlenmesi beklenen rolleri konu almaktadır. Literatürde uygulamalı sosyal bilimler, toplumsal alanlara yönelik ve stajla beraber uygulama eğitimlerinin verildiği psikoloji ve psikolojik danışmanlık, sosyoloji, sosyal hizmetler, siyaset bilimi, ekonomi, antropoloji, arabuluculuk ve demografi gibi bilim ve çalıșma alanlarını kapsamaktadır. Çalışmada, Türkiye bağlamında, sosyal bilimlerin yaşadığı ithal kavramsallaşma sorununu ve bilimsel altyapıdaki azgelişmiş uygulama dinamikleri üzerinde durulmakta ve yerel uygulama modellerine olan ihtiyaçlar tartıșılmaktadır. Çalıșmanın ilk bölümünde, sosyal bilimlerin kavramsal çerçevesi ortaya koyulmakta, doğu ve batı eksenli altyapısı ve tarihsel gelișim süreçleri göz önünde bulundurularak temellendirilmektedir. Sonraki bölümde, sosyal bilimlerin, bilim dünyasındaki konumunu metodolojik altyapısı, teori ve uygulama düzeyinde karșılaşılan güçlük ve önyargılar ele alınmaktadır. Son bölümde ise, araștırma odaklı teori-uygulama modelleri geliştirmek adına sorumlu olabilecek paydaşlar ve olası araştırma konuları tartışılmaktadır.
\end{abstract}

Anahtar Kelimeler: uygulamalı sosyal bilimler; uygulamalı psikoloji; kültürel uyarlama, disiplinlerarasılık

\section{Issues of Applied Social Sciences in Turkey: With a Focus on Applied Psychology}

\begin{abstract}
Current paper contemplates on some of the major issues social sciences of Turkey experience in the context of -applicability of social policies and education- with a specific focus on Psychology, hindering dynamics and processes on the way of building applied visions, and universities' responsibilities over responding to these needs. Applied social sciences generally responds to those areas that responds to social needs with a curriculum combining theory research and practice such as counselling psychology, counselling, sociology, social work, political sciences, economics, anthropology, mediation and demography. In this junction, current focus shifts to Turkey, with an aim to understand its problems around utilising imported theoretical concepts, in which their practice underdeveloped or never elaborated, and underlies the need for developing culturally adapted local practice models. To do so, first part starts with laying out the conceptual framework of social sciences and what they account for- going through the history of applied social sciences by examining its eastern and western origins. The next part then looks into the methodological infrastructure it possesses within the world of sciences considering the difficulties and prejudices faced at the level of theory and practice. The last part concludes with the roles all parties should take part and possible research directions to achieve a more balanced theory-oriented research practice.
\end{abstract}

Keywords: applied social sciences; applied psychology; cultural adaptation; interdisciplinary

\section{SOSYAL BILIMLERE KAVRAMSAL BAKIŞ}

Sosyal bilimler, toplum ve bireylerin birbirleri ile olan ilişkilerini inceleyen birçok akademik disiplinin çatı kavramı olarak karşımıza çıkar. Bu sebeple alt disiplinle-

*Yazışma Adresi / Address for Correspondence:

Zehra Erşahin, Email: zehra.ersahin@asbu.edu.tr

Geliş Tarihi / Received Date: 06.08.2019

Kabul Tarihi / Accepted Date: 22.08.2019

Doi: 10.26701/uad.602704 rinin yanı sıra farklı bilim ve ana bilim dallarına da temel oluşturacak bir yapı arz eder. Tüm dünyada farklı isimlerle örneklerine rastladığımız bu bilim dalları psikoloji, sosyoloji, ekonomi, politika, işletme ve yönetim, tarih, edebiyat, antropoloji, arkeoloji, hukuk ve dil çalışmaları alanı olarak değerlendirir. Her ne kadar sosyal bilim ifadesi, 19. yüzyılda çıkış noktası olan sosyoloji alan çalışmalarına karşılık gelse de bugün karşımıza bahsi geçen konu alanlarına kuramsal ve kavramsal bir çatı olarak evrilegelmiştir. 
Günümüzde sosyal bilimcilerin iki farklı metodolojik bakış açısı üzerinden çalışma alanlarına yaklaştığ 1 düşünülebilir. Pozitivist sosyal bilimler, toplumu anlamlandırma çabalarında doğa bilimlerinin metodolojik yaklaşımlarını kullanarak 'bilim' anlayışlarını 16. ve 17.yy'da hızlanan Avrupai modernleşmenin çizgisinde tanımlarken; yorumlayıcı sosyal bilimler kanıtlanabilir veya çürütülebilir teoriler geliștirmenin aksine sosyal kritik veya sembolik yordalayıcilık yaklaşımları üzerinden bilim kavramını çalışırlar. Dünya genelinde yaygın olarak sosyal bilimciler artık daha eklektik bir bakış açısıyla karma yöntemler kullanmakta; böylece sosyal araștırma olgusunun ve alt disiplinlerinin kendi yöntem ve tekniklerini üretme ve kullanmada disipliner bir otonomi geliştirmesini desteklemektedirler.

Sosyal bilimlerin karşı karşıya geldiği yöntemsel zorluklar hem nasıl araştırma yapılması gerektiği hem de nasıl bir araştırmacı yaklaşımının çalışmalara yöneltilmesi gerektiği sorularının da temel dayanağıdır. Nitekim doğa bilimcileri tarafından geliştirilen kuram ve yöntemlerin kendi bağlamında değerlendirilip uyarlama yapılmadan uygulanması doku uyuşmazlığı yaratabileceği gibi araştırma sorusuna karşılık gelmeyen cevapları da doğurabilmektedir. Örneğin 1960'lı yılların başında Avrupa'ya işçi olarak alınan göçmen/yabancıların okul çağındaki çocuklarının seçkinci bir yapıya sahip olan Alman eğitim sistemine yerleștirilmelerinde rol oynayan zekâ testlerinde kültürel kodlamalarda başarısızlıkları yüzünden büyük çoğunluğunun yardımcı işçi olarak yetişecekleri Hauptschule'ye (ilköğretime) veya öğrenme zorluğu çeken çocukların gittikleri Sonderschule/ Förderschule'lere yönlendirildikleri kayda düşmüştür (Baran, 2002).

Kendi bağlamında gerçekleşmemesi sebebiyle ülkemiz otoritelerinin kontrolü dışında süregelmiş bu durumun ülke içinde de çok farklı bir akış izlediği tartışmalıdır. Nitekim Anadolu Üniversitesinin proje desteği ve Milli Eğitim Bakanlığı’nın uygulayıcı ve uygulama desteği ile Türkiye'nin ilk yerli zekâ ölçeği olan Anadolu-Sak Zekâ Ölçeği'nin geliştirilmesi çalışmalarına ancak 2015'de başlanmıştır. Her ne kadar zekâ ölçeği uyarlama çalışmaları Türkiye'de 1915'e dayansa da günümüze kadar yapılan çalışmalar bir uyarlama kültürü oluşturmakla sınırlı kalmıştır. Proje IQ olarak adı geçen bu çalışmanın hem yerli bir zekâ ölçeği geliștirmek hem de uyarlama kültürünü kırarak yeni zekâ ölçeği geliştirme çalışmalarına öncülük edeceği umulmaktadır.

Böylelikle örneğin Türk kültürüne özgü sembol ve dil kullanımının sağlandığı ölçekte, yabancı testlerde kahvaltıyı tanımlayan 'kruvasan' ifadesi yerini 'zeytin, peynir'e bırakarak şekillendirilmiştir. Amerikan futbol topundaki dikişleri silerek çocuklara neyin eksik olduğu sorulduğunda Türkiye'deki çocukların 'firın küreği' ifadesi kültürümüzde yeri olmayan bir nesnenin Türkiye örneklemleri bağlamında sadece uyarlama bağlamında ne kadar yanıltıcı ve ölçümü yapılmak istenen olguyu ne denli az temsil ettiğinin bir göstergesidir. Günay (2018) bu durumun zihin tembelliğine de yol açacağını ifade ederken, toplumların mensuplarınca kendilik değerleri üzere inşa edilmesi gereğini vurgular. Yalnızca birkaç örneğini bahsettiğimiz ancak bunun gibi bağlamı dışında geliştirilmiş ve sadece uyarlama çalışmaları yapılarak etki alanı bu derece geniş kavramsal çalışmalara bilgi veren bu tür çalışmaların nasıl ve hangi kıstaslara uygun değerlendirildikleri ithal bilim anlayışı adına bir sorunsalı ortaya koymada düşündürücüdür. $\mathrm{Bu}$ çerçevede alınan mesafeye tarihsel bir bakış açısı sunmak gerekmektedir.

\section{UYGULAMALI SOSYAL BILIMLERE TARIHSEL BAKIŞ}

Sosyal Bilimin tarihi 1650'ler sonrası Aydınlanma Dönemi ile başlayan Doğa Felsefesi doktrinlerindeki bilimselliğe bakıș açısındaki devrimsel dönüşüm ile başlar. Zamanın ahlak felsefesi ile ön plana çıkan bu bilim alanı Endüstri Devrimi ve Fransız Devrimi'nin etki alanı dahilinde farklı sosyal grupların etkileşimlerini inceleyen deneysel ve uygulamalı bilimlerden etkilenmiştir Peck, Peabody, \& Richardson, 1897). Sosyal bilimin ayrı bir çalışma alanı olarak ilk kullanımı 18.yy Modernleşme Dönemi'ne aittir (Thompson, 1824). Comte'nin 'science sociale \& social physics (sosyal bilim \& sosyal fizik)' olarak ifade ettiği bu dönem çalışmaları doğa bilimleri alanındakilere benzemesi itibariyle olumlu edimlere dayalı bilgiye odaklanan Pozitivizm'e odaklanmış, metafizik önermelerden uzak durulmuştur (Kuper \& Kuper, 1985).

Sonraki dönemi takip eden gelişmeler beş farklı yol izlemiştir. Comte, Amerika Birleşik Devletleri ve Avrupa'nın çeşitli bölgelerine yayılan sosyal ve büyük çaplı istatistiksel araştırmalara önderlik ederken, Durkheim ve Pareto sosyal gerçekler üzerine eğilmiştir. Diğer yandan Weber sosyal olguyu anlamada nicel ve niteli bir arada kullanan metodolojik açılımlarda bulunurken, Ekonomi alanında nicel yöntemlerin kullanıldığı bir pozitif bilim anlayıșı oluşmaya başlamıştır. Son olarak yorumcu ve pozitivizm karşıtı Weber akımı, bilgi ve sosyal değerlerin ilişkisel ağını netleștirmek üzere teori ve uygulamanın apayrı ancak vazgeçilmez iki yönü olduğunu savunmuştur (Kuper \& Kuper, 1985).

Aydınlanma felsefesinin getirdiği bu akımlar 20.yy'ın başlarında ciddi oranda sorgulanmış, nitel ve nicel araștırma yöntemleri arasında kurulmaya çalışlan sınırlar örneğin teori kurgulamada matematiksel çalışmaların tercih edilmesiyle zayıflamıştır. Böylelikle sosyal bilim alanı yoğunlukla nicel yöntemlerin kullanıldığı bir çalışma alanı haline gelmiş, disiplinlinler arası çalışmalara araştırmacllar motive edilmiştir (Vessuri, 2002). Örneğin Klinik Psikoloji bilim alanı II. Dünya Savaşı ardından çıkan tanı ve terapötik destek ihtiyacına yönelik Gaziler İdaresi (Veterans Administration) tarafından hastane ve kliniklerde desteklenme sürecinde uygulama alanını geliştirmiştir. 
Bu akımın takip ettiği şekliyle günümüzde Nöro-psikoloji, sosyo-biyoloji veya sosyolojisi bu çalışma alanlarına örnek verilebilir.

Yakın dönem Avrupası'nda Popper ve Parsons artan bilgi birikimini, gelişen toplum ve sosyal olguları ele alacak düzeyde geçerliliği kabul edilen bir sosyal teorinin nasıl geliştirilebileceğine dair alan çalışmalarına öncülük etmișken, 21. yy sosyal bilim dünyası ekonomi alanında bir çeșit emperyalizme halen ev sahipliği yapmaktadır (Lazear, 2000). Zira, 21. yüzyıl sosyal bilimi kendi teorik, metodolojik ve uygulamadaki çıkmazlarını tanımlayıp çözme konusunda daha açık bir profil çizmektedir (Wallerstein, 2003).

Konuya İslam düşüncesinde ilimlerin tasnifi gözüyle baktığımızda 19.yy'ın sonlarına kadar İslam coğrafyasında bilimsel her türlü çalışma alanının 'ilim' başlığı altında ele alındığ göze çarpar. Farabi (951) ile başlayan 'İhsau'lUlum' (İlimlerin Sayımı/Tasnifi) geleneğinde bunu açıkça görebiliriz (Türker, 2011). İlk örnekleri Harezmî, Amiri ve İbn Hazın gibi yazarların eserlerinde görülen ilim tasnifinde şer'i ve gayr- $\iota$ şer'i ayrımı İbn Sina, Gazzali gibi alimlerin katkılarıyla İslam düşüncesinin hakim tasnifi haline gelmiştir. Bu tasnifte şer'i ilimleri dini ilimler temsil ederken; gayr-1 şeri ilimler de sosyal hayatın ve bireysel anlamda hayatı ikame etmenin ilmi olarak değerlendirilir. Yalnız bu noktada vurgulanması gereken husus teorik ve pratik arasındaki farkın yetkinleşmeye işaret etmediği; ancak dindarlık derecesini ifade ettiğidir (Türker, 2011). Çünkü her türlü değeri ve kurumu din, vahiy ve nübüvvet üzerine dayalı bir kültürde, benzer tartışmaların felsefe ve ona bağlı olarak tüm bilimsel etkinliklerde bir yer, bir yaşama imkânı verebilecek tarzda olumlu bir çözüme kavuşturulması büyük önem taşımaktaydı. Bu çerçevede takva kavramının belirleyici olduğu bu tasnif yine de Gazzali'nin "eşyanın hakikatini araştırma iddiasıyla ortaya çıkan üç gruptan (mütekellimler, filozoflar ve süfiler) yalnızca sufileri hakikatleri tahkik seviyesinde bilen zümre" (s. 551) olarak nitelendirmesinde sufilerin müşahede yöntemini kullanırken diğerlerinin nazar yolunu kullandığına dikkat çekmektedir. Bir başka deyişle, İbn Sina tecerrüdün nazar yolunun yanısıra müşahede yöntemi olan namaz, zikir, oruç vb. uygulamalarla gerçekleşeceğine inanır. Pozitif bilim ve ilim ayrımı tartışmalarının İslam dünyasının uzun yıllar gündemini 'bir sorun olarak' meşgul etmediği; mevcut haliyle bakıldığında uygulamanın teoriye olan üstünlüğü vurgusu dikkat çekicidir. Ancak tarihsel süreçte, İslam coğrafyasında uygulama alanındaki gerileme, onu pozitif bilimin ışığında 'ilim' olmakla kısıtlamış, bu da sosyal bilimcilerin uygulamaya dönük metodolojik açılımlarını gölgelemiştir.

\section{UYGULAMALI PSIKOLOJI'DEN HAREKETLE UYGULAMA TECRÜBELERI}

Bugünün erişilebilir bilgi dünyasında, muazzam çeşitlilikteki bilgi birikimi, insan davranışı ve zihinsel süreçler üzerine bir asrı aşkın kabul edilmiş ve teori haline gelmiş pek çok kavram ve yapının temellerini sarsmaktadır. Psikolojinin akademik temellerinin çoğunlukla Kuzey Amerika ve Avrupa'da geliştiği bilinmektedir. Temellendiği ve geliştiği coğrafyanın düzleminde bu bilgi birikimi, uzun yıllar insan biliş ve davranışlarını ve sosyal süreçleri harekete geçiren dinamikleri ve devinimleri anlamada temel kabul edilmiş ve evrensel düzeyde doğru varsayılmıştır. Keza 2010 yılında yapılan bir çalışma, o güne değin Psikoloji araştırmalarına katılımcıların \%90'dan fazlasının rastgele bir örneklemi ve evrenden seçilmediği; daha ziyade batılı, eğitimli, sanayileşmiş, zengin ve demokratik (WEIRD) ülke topluluklarını temsil ettiği iddia edilmiștir (Henrich vd., 2010). Genelleme olasılığı oldukça kısıtlı olan bu kitlenin temsil gücü düşündürücüdür. Ancak son yıllarda kültürlerarası araştırmaların artması, ve bilgiye global düzeyde erişimin kolaylaşması Psikoloji bilimine birey, toplum ve hatta coğrafi bağlamda bakma şansı ve özgürlüğü vermiştir. Kültürel ve kültürlerarası yapılan tüm bu çalışmalar değişkenlik ve evrensellik kavramlarını yeniden sorgularken; düşünce eğilimlerinin mikrodan makroya kültürel düzeyde farklılaştığını ve bu bilişsel haritalamanın genetik ve çevresel kodlarla hafıza, dikkat, algı, akıl yürütme gibi temel bilişsel eylemleri belirlediğini ortaya koymaktadır. Psikoloji literatüründe tüm bu teorik tartışmaların gündelik hayatta vücut bulduğu yer uygulamalı psikoloji bilim alanı olmakla beraber, medeniyetin pratik çabalarıyla tam temas etmesi halinde ancak fayda sağlayacağı düşünülebilir. Nitekim çoğulcu bir toplumda "kendilik algısı" kavramını kazara bireyci bir temelde analiz eden bilimsel yaklaşımın; tüm okul, hastane, hukuk, endüstri, sanat alanlarında, bireyin, psikolojinin konu ettiği sosyali, ruh sağlığını, fizyolojisi veya ilişki kurma becerilerini eksik veya çoğunlukla hatalı değerlendirmesi kaçınılmaz olacaktır.

Tam da bu noktada Türkiye'nin sosyal bilimcilerinin kendi varsayım ve yöntemlerini geliștirirken uygulamada hız kazanmaları gerekliliği gündeme gelmelidir. Çalıșma konusu kiși, toplum, ekonomi, ideoloji, demokrasi, sağlık ve eğitim gibi kavramlar olan araştırmacıların bu kavramlara toplumun kendisine özgü bir ürünü çerçevesinden mi yoksa evrensel geçerlik ilkeleri bağlamında mı bakması uygun olur sorusu gündeme gelmelidir. Nitekim sosyal yaşam, $x, y$ ve z örüntülerinin neden-sonuç ilişkileri çerçevesinde özetleyip, basit önermelere indirgenemeyecek kadar karmaşık ve çok boyutlu bir yapı arz eder. Böylelikle doğa bilimlerinin pek çok benzer durumu genelleyici bir açıklama ile nedensellik örgüsünün yerini araştırmaya konu olan olguların kendi özgünlüğü içerisinde karmaşıklığını anlama çabasına bırakmalıdır. Bu yaklaşım tarzını temelde zorlaștıran sorunlardan biri doğa bilimlerin genelde araştırma nesnelerinin kendilerinden bağımsız olmalarıyken; sosyal bilimcilerin araştırdıkları olgu veya nesnelerinin bir parçası olmaları durumudur. Bir başka deyişle insan, sosyalin hem yapı taşı hem ustası hem de inşaatın kendisidir (Berger \& Luckmann, 1966). Bu nüans 
özne-nesne argümanı üzerinden araștırmacının nesnelliğini sorgulatırken aynı zamanda nesnel bilimin kanunları gereği geçerliğini de irdeler.

Nitekim sosyal bilimlerin temel ilgi alanı olan insanın neyi neden yaptığını açıklarken bu karmaşık örüntü içinde ele alınması kaçınılmaz olduğundandır ki asırladır filozoflar aynı hususları tartışa gelmiş ve mutabakata varılabilen çok az konu olmuştur. Örneğin Eflatun'dan bu yana adalet kavramı tartışılagelmiş, bugün farklı disiplinler konuya farklı bakış açıları getirse de ortak bir hükme varılamamıştır. Sosyal bilimlerin diğer bir çalışma alanı olan Siyaset Bilimi ve Uluslararası İlişkiler literatürü halen M.Ö. 4. yüzyıla (460-395) ait, asırlarca tarih çalışmalarını etkileyen Thukydides'in Peloponez Savaşı'nın dinamiklerine dair ele aldığı 8 ciltlik kitabına referans verir.

Aynı zamanda, tüm bu belirsizlik hali sosyal bilimlerin birikimli ve zengin dünyasına katkı olarak da değerlendirilebilir. Psikoloji bilim alanından hareketle, Laing (1960) Bölünmüş Kişi adlı eserinde işlevsiz aile ilişkilerine şizofreninin etiyolojisinde yer verirken, kendi çatışmalı aile örüntülerinden hareket etmiş, yaşantıları motivasyon kaynağı olmuştur. Bireylerin, özelde araştırmacının, içsel gerçekliği yaşantı süreçleri, temsilleri ve hatta duygulanımlarının bir koleksiyonu olarak düşünüldüğünde bireyin inşa ettiği bir dünya (ve nesneleri) algısı bilişsel algı süreçlerinden temel alır. Bu analist için bir varlık hali taşır ve etkisi fiziksel realite kadar güçlü ve gerçektir. Araştırmacı diş gerçekliğinde çevresi, bedeni ve toplumdaki yerini daha maddi bir realite üzerinden okur. Böyle bir açılım her ne kadar diyalektik bir bakış açısı sunsa da örneğin psikoloji biliminin gelişmesinde oluşturduğu tartışmalı kuramı ile çok büyük katkı sunan Sigmund Freud'un nevrotik ve histerik bir kişilik yapısı üzerinden kurguladığ kavramsal yapının gücünü de ortaya koyar. Bu örnekler, sosyal bilimlerin öznel deneyimlerden soyutlanamayacağı ve soyutlanmaması gerektiğine dair önemli bir örnektir. Bilimsel kavramların ve sosyal ilişkilerin inşası arasındaki dinamikleri yadsımamak, araştırmada fenomeni anlamakta uygulamanın önemine dikkat çekmelidir. Keza, bilimin her türlüsünün kendilerini bir bilgi birikimi üzerine inşa ettiğini iddia eder ve bu durum bilimsel bilginin sürekli gelişmesini sağlar.

Nitekim, 2010 yılı Dünya Sosyal Bilim Raporu (Caillods \& Jeanpierre, 2010) süregelen tartışmaların yakın zamanlı birkaç örneğini gündeme almıştır. Rapor, 2008'deki küresel krizi öngöremeyen sosyal bilimcilerin, disipliner yaklaşımlarına ve temel kuramlarına muhafazakâr ölçüde bağlı kaldıkları, günümüz şartlarında hızla dönüşen toplumsal ve ekonomik dengelere vakıf olmadıkları hususlarında eleştiriler getirmektedir. Ülkemizde sosyal bilimlerin diğer pozitivist bilimlerin gölgesinde kalması ve kendini yineleyememesi kanımızca 'nedensellik' çıkmazında uygulamalı bir araştırma disiplini geliştirememesi, alana disipliner ve muhafazakâr bir bakış açısıyla teamülü ve belirli bir inanca sahip olmaksızın çeşitli üsluplar arasın- dan kendine uygun olanı seçerek ilerlemek kaydıyla eklektisizm gayreti içerisinde olması olarak düşünülebilir.

Büyük resmi görmede, sosyal bilimlerin farkı alanlarını birbirileri ile ilişkilendirebilmek için, izole edilmiş bir bilim anlayışını veya eklektisizmi tek başına ele almak, ampirik çalışmalarla desteklenmediği takdirde her türlü sosyal faktörü ilgili davranışların sebebi olarak gösterme kolaycılığından sosyal bilimciyi uzaklaştırmayacaktır. Örneğin, internet ortamında çeşitli sosyal medya mecralarında geçirilen vaktin aile dinamiklerine etkisini araştırmak isteyen bir sosyal bilimci, tercih edeceği araştırma teknik ve yöntemlere göre data toplayarak analiz ve değerlendirme süreçlerine girecektir. Tercihi, örnekleme ve standardize edilmiş testler aracılığıyla demografik ve sosyolojik/psikolojik testler uygulamak olan araștırmacının kontrol ettiği değişkenler dâhilinde diğer gruplarla karşılaştırma yapması, ilişkisel örüntüler ortaya koyması beklenir. Diğer taraftan tercihi demografik elemeler sonucu amaçlı bir örnekleme ulaşarak mülakat yöntemi ile vaka analizi yapmak olan araştırmacının bu verileri başka ailelere genellemesi beklenmez. Her iki örnekte de görülebileceği üzere bir durum ve ilişki ağı ortaya çıkarmada farklı metotların uygulama düzeyinde farklı yansımaları olacak, ancak her ikisi de doğrulama veya buluş bağlamında ampirik düzeyde test edilmesi sonrası bilimsel boyut kazanacaktır.

Türkiye'de sosyal bilimlerin Batıdaki muadilleri ile teorik, metodolojik ve uygulama boyutlarında ithal bir bilim anlayışına sahip olduğu tartışılagelen bir sorun alanıdır (Esgin \& Arslan, 2011). Tartışmalar daha ziyade Batı'nın tanımladığı sosyal bilim algısı çerçevesinde şekillenmekte, problem alanları da paralel doğrultuda şekillenmektedir. Ancak sosyal bilim-doğa bilimi ayrımı ülkemizde Avrupa'da geliştiği düzeyde barışık ilerlememiş, hala tartışmakta dahi zorlandığımız bir mesele olarak gündemdeki yerini korumaktadır (Sezer, 2006). Ülke gerçeklerine uygun, dokusu ile hemhal bir sosyal bilim anlayışı geliştirmek üzere araştırmaların niteliği, araştırma sorusunun doğası/muhatabı/bilimsel kodları ve hatta yetersizlikleri gibi sorunları konuşmaktan ziyade halen Batı dünyasının doğa ve sosyal bilim metodolojilerinin uyarlanmaksızın kullanıldığı, teorisi oluşmadan deneyimlemelere gidildiği, analitik kavramlar üzerinden pozitivist bir bakış açısıyla oluşturulmuş bir sosyal bilim anlayışı ile ithal bilim üretilmektedir. İlginçtir ki Batı'da sosyal bilimler bu tartışmaları 19. yy. itibariyle sonuçlandırmaya ve hatta sosyal gerçeğe uygun şekillendirmeye başlamışken, günümüz Türkiye'sinde sosyal bilimlerin, sosyal yaşamın üretilmesindeki çok sınırlı katkısı düşündürücüdür. Hap şeklinde tabir edilebilecek yöntemlerle, yalnız güncel olgularla meşgul olan bu arayışlar bilimsel bir anlayışın oluşmasındaki en temel soruları da sorunları da göz ardı bırakmaktadir.

Bunun doğal sonucu olarak da küresel olandan azami düzeyde etkilenen ülkemizde, toplumsal dokuya ve ih- 
tiyaca özgü; sosyal olguların coğrafi, kültürel ve sosyal ilişkiler düzeyindeki farklı yansımalarını teori, uygulama ve metodolojik boyutta ele almayan bir bilim anlayışını ülkenin tüm eğitim kurumlarının da pekiştirdiği ve tekrar ürettiği bir bilim anlayışı ile karşı karşıyayız. Bilhassa siyaset ve bilim arasındaki ilişkiler bağlamından çıkarak politikleştiği, üniversiteler düzeyinde ise daha çok kendi ihtiyacını karşılayabilecek eğitim programlarının üretilmediği düşünüldüğünde, büyük çerçevedeki bu 'meşruiyet' (Esgin \& Arslan, 2011) sorunu öncelikli gündeme alınmalıdır.

Bu sorunlara Türkiye'deki üniversite yapılanması ve politika-bilim ilişkisi gibi unsurlar da eklenince, sosyal bilimlerin meşruiyeti ve itibarı her geçen gün daha da sorgulanmaktadır. Keza sorunlara çözüm arayışında olanlar ve politika üreticileri arasındaki mecra belki de en çok sosyal bilimcinin uygulamaya dayalı kullanacağı alanı ile ilişkilidir. Yalnız her uygulama alanının bir teorisi ve metodolojisi olması gereğinden yola çıktığımızda yaşanılan sıkıntıları kuramsal düzeyde yine deneysel \& deneyimsel süreçlerden geçirmek güçlü bir sosyal bilim zemini oluşturacaktır. Madalyonun diğer yüzünde sosyal bilimlere ve bilim insanlarına dönük toplumun ve siyasilerin olumsuz algısı bu yapılanmayı pekiștirici bir rol de oynayabilir. Nitekim politikalar belirlenirken, yöneticilerin mevcut araştırmalar veya alanın uzmanlarından yararlanmak yerine, bir bilim insanı edasıyla tavır alması, sosyal bilimcilerin üretime ve uygulamaya dönük çıtılar üretseler dahi dikkate alınmayacakları (ön)yargısını oluşturabilir. Bu önyargı eğer karşılıklı ise, politikacıların sosyal bilimlerde uygulama alanlarının geliştirilmesi veya çözüm süreçlerine dahil edilmesine yönelik adım atmalarını da engelleyebilir. Son 50 yılın kalkınma politikaları bu görüşü destekler niteliktedir. Örneğin 1963'te kurulan Türkiye Bilimsel ve Teknik Araştırma Kurumu (TÜBİTAK) doğa ve tıp bilimleri alanlarında temel ve uygulamalı bilim araştırmalarını geliştirmek amacıyla bugüne kadar varlığını sürdürmüş; fen, matematik, tıp ve teknolojik alandaki gelişmelere kaynak sağlamıştır. Buna karşın son dönem kalkınma planları arasında yer alan bir sosyal araştırma kurumu tasarısı (Türkiye Ekonomik ve Sosyal Araştırmalar Kurumu, TESAK) ise halen askıdadır (Tekeli, 2005).

\section{UYGULAMALI SOSYAL BILIMLER VE ÜNIVERSITELERIN ROLÜ}

Sosyal bilimlere olumsuz bakış açısı ile üniversitelerin sosyal bilim kimliği arasında da aynı fasit daireden söz edilebilir. Söz gelimi, Türkiye'nin Sosyal Bilimler adını taşıyan veya uzmanlık alanı olarak sosyal bilimlere yatırım yapmış bir üniversitesi son 4 yıla kadar olmamıştır. 2017 istatistiklerince Türkiye'nin başarı sıralaması yüksek ve bilime katkı sağlayan ilk 3 üniversitesi Ortadoğu Teknik Üniversitesi, Hacettepe Üniversitesi ve İstanbul Teknik Üniversitesi olarak belirlenmiştir. Her ne kadar aralarında Hacettepe Üniversitesi ismi itibari ile teknik kimliği ile ön plana çıkmasa dahi, araştırma merkezleri tekno-kent, tıp, mühendislik, biyoloji \& kimya ve teknoloji transferi merkezli şekillenmiş, dolayısıyla ağırlıklı olarak fen, matematik, tıp ve mühendislik bölümlerinin öğrenci başarı sıralamasında daha yüksek puan diliminden öğrenci almıştır. Bu durum toplumun önemli bir kesimi için eğitim sistemimizin neredeyse her kademesinde sayısal ağırlıklı eğitim kurumlarının tercihini pekiştirmekte, doğa bilimlerine yapılan yatırımın beyin takımına yapıldığı algısını pekiştirmektedir. Sosyal bilimlere yönelik tartışa geldiğimiz olumsuz bakış açılarının böyle bir algı birikimine hangi parametreler üzerinden neden olduğu yeni araştırma konusu haline gelmektedir. Bu algının, sosyal bilimlerin kendi içindeki problemlerle, sosyal bilimcilerin akademisyen kimliğiyle ve üniversite yapılanmasıyla ilişkisini ortaya koymak isteyen Esgin ve Arslan'ın (2011) 1535 akademisyen üzerinde yaptığı araştırma bulguları bu kanaati destekler niteliktedir. Nitekim araştırmacıların "Bilim ve üniversiteye ilişkin bir konu gündeme gelince Türkiye'de insanların aklına genellikle, beyaz önlüklü bilim adamları, laboratuvarlar ya da tıp doktorları gelir" (s. 3) yargisına akademisyenlerden \% 79 oraninda olumlu yanıt gelmesi şaşırtıcı değildir. Uygulamalı bir sosyal bilim yapılanmasının engelleri bağlamında "Ülkemizde bilimsel çalışmaları desteklemek amacıyla kurulan, TUBİTAK ve TUBA gibi kuruluşların proje desteklerinde önceliği doğa bilimlerine verdikleri söylenebilir" (s. 3) yargısı ise \% 63 oranında destek bulmuştur. Üniversite içinden gelen bu olumsuz algının kurumsal gelişimde karşımıza çıkan politika odaklı arayışlar (Heper, 2000), alanda akademisyen yetiştirmedeki yetersizlikler (Güvenç, 2000) ve üniversite vizyon ve misyonunun yönetim ve eğitimciler nezdinde tanımlanmasındaki zayıflıklar çerçevesinde şekillendiği aşikardır.

Tabanda akademisyenlerce geliştirilecek bu açılımın hukuki ve idari çatı altında değerinin ve sürdürülebilirliğinin teşvik ve temin edilmesi gerekir. Örneğin halihazırda sosyal bilimlerde doçentlik kriterleri eser puanlarının yazar sayısına eşit bölünmesi politikasıyla yazarlar için işbirliği ve uygulamayı neredeyse imkansız hale getirmektedir. Bu politika, doğasında zaten uygulamalı olan mühendislik ve sağlık bilimlerine uygulanmamakta, halen teşvik edici niteliğini korumaktadır. Türkiye akademisinde sosyal bilimlere uygulama niteliği veya misyonu zaten yüklenmemekte midir? sorusu, bu ideale ulaşılmasında sistemin böylesi kısıtlamaları üzerinden düşündürücüdür.

Bu çerçevede Türkiye'nin artan sayıda sosyal bilimler alanında kurulmuş devlet üniversitesi bünyesinde bu fasit daireyi kırmasının yolu; yönetimden, en alt birimlerde çalışan elemanlara, akademisyeninden idarecilerine kadar aynı misyon ve vizyona sahip öğrenci, bilim insanı, kalifiye eleman yetiştirme hedefi ile başarılabileceği kanaati temel alınabilir. Böyle bir güç uygulamalı bir bilim anlayışını sosyal ve teknik olarak kullanılabilen, bilgiyi hem üretme hem de aktarabilme idealinden alacaktır. Sosyokenti, sosyal laboratuvarları, yükseköğretim kanunları ve yönetmeliklerin izin verdiği ölçüde öğretim programları- 
nın bu ideale yönelik șekillendiği kurumlar acilen ihtiyaç arz etmektedir.

Bu ideal; sosyal bilim çalışma alanlarında - yoksulluk, işsizlik, iş yaşamındaki sorunlar, insan hakları, iş gücü sarfiyatının çevreye ve topluma etkileri, sürdürülebilir iş, hukuk \& sosyal politikaların geliştirilmesinin yanı sıra, kentleşme, etnik gruplar ve azınlıklar, göç ve uyum, eğitim ve sosyalleşme sorunları, toplumsal cinsiyet eşitsizlikleri, kadının toplumdaki yeri, farklı gelişimsel dönemlerin ihtiyaç ve sorunları, medya ve tüketim alışkanlıklarını anlamak, araştırmak, katkı sunmak adına uygulama odaklı yaklaşmayı öngörmektedir. Üniversitelerin bunu için de bulunduğu coğrafyayı tarihiyle, kültürüyle, insan faktörü ve ekonomik ve siyasi konjonktürüyle ele almayı kıstas kabul etmesi ile başarmaları mümkündür. Üniversiteler, tüm bu çalışma alanlarının dinamik birer parçası olduğu bilinci ile de disiplinler arası ve uygulamalı yaklaşıma öncü olacaktır.

\section{SON SÖZ}

Tüm mevcut tartışmalar çerçevesinde bilginin bilimsel ve toplumsal faydaya dönüştüğü, duvarları olmayan, bilim insanları ve kurumlarınca üretilebileceği fikri, ideal olmasına karşın Türkiye gerçeğinde an itibariyle reel karşılık bulmamaktadır. Kanaatimizce uygulamaya dönük sosyal bilim faaliyetleri; sadece bilimsel araştırmanın ötesinde, 'araştırma' ve 'gelişim' ya da 'bilim' ve 'mühendislik' olarak adlandırılan uygulama araçlarını birlikte kapsar. Bir bütünü arz eden bu yapı; bilim insanının halet-i ruhiyesini, bireysel ve toplumsal zihni kurguları, kurumsal desteği, disiplinler arası ilişkileri, bilim insanları ile iletişimi ve bilim dışı kaynakların ve bilim dışı becerilerin kullanılmasını da doğal olarak içermelidir.

Nitekim, uygulamalı sosyal bilim denildiğinde dünya literatüründe daha ziyade toplum yararı gözetilen alanlara yönelik stajla beraber uygulama eğitimlerinin verildiği psikolojik danışmanlık, sosyal hizmetler, uzlaştırma/ arabuluculuk, şehir planlama gibi bilim alanları akla gelmektedir. Ancak ortak özelliği disiplinlerarası ve uygulama ekseni olan bu alan günümüzde disipliner yaklaşımın azalması, bilim alanlarının hibridleşmesi, piyasanın taleplerinin birden fazla alanda profesyonelleşmiş adaylara yönelmesi sonucu üniversiteler taleplere cevap vermek üzere interdisipliner eğitim programlarına yönelmişlerdir. $\mathrm{Bu}$ açılım üniversitelerde lisansüstü düzeyde interdisipliner programların artması (i.e. uygulamalı sosyal araştırmalar, denetim ve risk yönetimi, manevi danışmanlık) ve lisans eğitiminin ilk iki yllında derslerin ortak olması yahut seçmeli derslerin alan dışına açılması şeklinde kendini göstermektedir.

$\mathrm{Bu}$ bağlamda sosyal bilim anlayışının ve araçlarının; tanımlayan, açıklayan, analitik veya ayrıştırıcı olmak ile sınırlı kalmayarak, yaratıcı ve yapıcı/inşaa eden bir tutum sergilemeleri modern dünyanın 'gelişim' ve 'mühendislik' ile ifade edebileceğimiz uygulamalı sosyal bilimler anlayı- şına hizmet edebilir. Nasıl bir bilim insanı parçaları görmek için nesneyi ayrıştırır, yeni ilkeler ve bağlantılar kurar ve bir mühendis onları birleștirir, nedensel süreçlerle sonucu icat ederse; uygulamalı bir sosyal bilim bu analitik ve sentetik süreci bozup yeniden yaparak temin etme felsefesi ve araçlarını bir araya getirmek durumundadır.

Aynayı uygulamalı psikoloji bilim alanına çevirdiğimizde de durum farklılaşmalı, muhafazakâr tutumlar aşılarak bilhassa araştırma sahalarına daha cesur adımlarla girilmelidir. Örneğin, aynı olguya nicel yöntemlerin yanı sıra nitel lenslerle bakmanın, istatistiklerin doğasını anlamamızı kolaylaştıracağı muhakkaktır. Bugün biricikliğine vurgu yaptığımız insanın konu olduğu her alanda güncellenmekte olan psikolojik bilgi birikiminin ancak bu şartlarda test edilebileceği; ve tabiatına uygun kavram ve beklentilerle temsil edilebilmesi için alan uzmanlarının toplumsal faydayı önceleyen uygulama örneklerini artırmaları alan için öncelik arz etmektedir.

Tüm bu süreçlerin temini, ülkenin sosyal bilim alanlarındaki ithal bilim sorununun en temel çözüm araçlarından biri olarak değerlendirilebilir. Kültür, din, dil, tarih ve etnik coğrafyası ile bağlamı dikkate alınmak üzere mikro ve makro düzeyde toplum yapısının ve kamu kuruşlarının nasıl çalıştığını bilmek ve onları analitik düzeyde irdeleyen, tanımlayan, açılayan, yeniden üreten ve geliştiren bir uygulamalı sosyal bilim anlayıșı geliştirme sürecinin teminatı durumundadır.

\section{REFERANSLAR}

Baran, R. (2002). Federal Almanya Eğitim Yapısı ve Göçmen İş̧̧ Çocuklarının Eğitim Sorunları. Retrieved in May, 2017 from www.ozgurpolitika.org/2000/04/22/hab29.html

Berger, P. L. ve Luckmann, T., 1966, The Social Construction of Reality: A Treaties in the Sociology of Knowledge, New York: Irvington Publishers.

Bernstein, S., Lebow, R. N., Gross, J. \& Weber, S. (2000). God Gave Physics the Easy Problems: Adapting Social Science to an Unpredictable World. European Journal of International Relations, March, 6(1), 43-76.

Caillods, F. \& Jeanpierre, L. (2010). General Introduction, ISSC/ UNESCO World Social Science Report. Paris: UNESCO Publishing.

Columbian Cyclopedia (1897). Buffalo: Garretson. Cox \& Company.

Dreyfus, H. L. \& Robinow, P. (1983, Eds). Michel Foucault beyond Structuralism and Hermeneutics. Chicago: Chicago University Press.

Esgin, A., Arslan, F. (2011). Türkiye'de Sosyal Bilim Algısının Negatifliği ve Üniversitenin Misyonu Üzerine. Uluslararası Yükseköğretim Kongresi: Yeni Yönelişler ve Sorunlar, Ed. Durmuş Günay ve Ercan Öztemel, İstanbul: Deomed Yayıncılık, s. 384.

Günay, D. (2018). Türkiye'de Lisansüstü Eğitim ve Lisansüstü Eğitime Felsefi Bir Bakısı. Üniversite Araştırmaları Dergisi,1(2), 71-88.

Güvenç, B. (2000). Türkiye'de Sosyal Bilimler Gelişmeler ve Sü- 
reklilikler, Dünya'da ve Türkiye'de Bilim, Etik ve Üniversite. Türkiye Bilimler Akademisi Yayınları, s. 22-35.

Henrich, J., Heine, S. J., \& Norenzayan, A. (2010). The weirdest people in the world? Behavioral and Brain Sciences, 33(23), 61-83.

Heper, M. (2000). 2000'li Yılların Eşiğinde Türkiye'de Devlet ve Üniversite, Dünya'da ve Türkiye'de Bilim, Etik ve Üniversite. Türkiye Bilimler Akademisi Yayınları, s. 13-21.

Kuper, A., \& Kuper, J. (1985). The Social science encyclopedia. London: Routledge \& Kegan Paul.

Laing, R. D. (1960). The Divided Self: An Existential Study in Sanity and Madness. Harmondsworth: Penguin.

Lazear, E. P. (2000). Economic Imperialism. The Quarterly Journal of Economics. 115, 99-146.

Machlup, F. (1961). Are the Social Sciences Really Inferior? Southern Economic Journal, 27(3),173-184.

Peck, H. T., Peabody, S. H., \& Richardson, C. F. (1897, Eds). The International Cyclopedia, A Compendium of Human Knowledge. New York: Dodd, Mead and Company.

Sezer, B. (2006). Sosyolojinin Ana Başılıları. İstanbul: Kızılelma Yayıncilık.

Tekeli, İ. (1998). Toplum Bilimlerinin Önünü Açmaya Insan Modellerini Tartışarak Başlamak, Sosyal Bilimleri Yeniden Düşünmek. İstanbul, Metis Yayınları.

Thompson, W. (1824). An Inquiry into the Principles of the Distribution of Wealth Most Conducive to Human Happiness; applied to the Newly Proposed System of Voluntary Equality of Wealth. London.

Türker, Ö. (2011). İslam Düşüncesinde İlimler Tasnifi. Sosyoloji Dergisi, 22, 533-556.

Vessuri, H. (2002). Ethical Challenges for the Social Sciences on the Threshold of the 21st Century. Current Sociology, 50, 135-150.

Wallerstein, I. (2003). Anthropology, Sociology, and Other Dubious Disciplines. Current Anthropology. 44(4), 453-465. 